\title{
Mineral fertilization with macronutrients in castor bean, lineage UFRB 222
}

\author{
Antonio R. Cavalcante ${ }^{1}$, Washington B. de Lima ${ }^{1}$, Lucia H. G. Chaves ${ }^{1}$, Josely D. Fernandes ${ }^{1}$, \\ Felipe G. de Souza ${ }^{1} \&$ Simone A. Silva ${ }^{2}$ \\ ${ }^{1}$ Universidade Federal de Campina Grande. Campina Grande, PB, Brasil. E-mail: antoniosoledade@gmail.com - ORCID: 0000-0003-2591-9649; \\ washi_bene@yahoo.com.br - ORCID: 0000-0002-4391-7092; lhgarofalo@hotmail.com (Corresponding author) - ORCID: 0000-0002-9905-2315; \\ joselysolo@yahoo.com.br - ORCID: 0000-0002-1297-6962; felipeguedes.eng@gmail.com - ORCID: 0000-0002-2861-0287 \\ ${ }^{2}$ Universidade Federal do Recôncavo da Bahia. Cruz das Almas, BA, Brasil. E-mail: simonealves22@gmail.com - ORCID: 0000-0002-3017-6133
}

\begin{abstract}
The study was conducted to evaluate the effect of mineral fertilization on the growth and production of seeds and oil of castor bean (Ricinus communis L.) lineage UFRB 222. The experiment was carried out in a greenhouse of the Centro de Tecnologia e Recursos Naturais at the Universidade Federal de Campina Grande, PB, Brazil. A randomized block design with three repetitions and 14 treatments originated from a Baconian matrix was adopted. Reference doses were 50:300:150 kg ha-1 of $\mathrm{N}_{2} \mathrm{P}_{2} \mathrm{O}_{5}$ and $\mathrm{K}_{2} \mathrm{O}$. At the end of the study, plant height, stem diameter, number of leaves, leaf area, total seed number, total seed weight, total fruit number and oil production per plant were evaluated. On average, the nitrogen dose of $150 \mathrm{~kg} \mathrm{ha}^{-1}$ led to adequate values of growth and yield variables. For plant growth, $300 \mathrm{~kg} \mathrm{ha}^{-1}$ of phosphorus should be applied, since the differences in the increase of growth variables between this dose and the highest ones estimated by the equations were very small; for castor bean production, the best applied dose was $600 \mathrm{~kg} \mathrm{ha}^{-1}$ of phosphorus. The application of potassium increased the leaf area, number of seeds and production of oil, and the best dose was $300 \mathrm{~kg} \mathrm{ha}^{-1}$. Phosphorus was the nutrient that promoted the highest production of oil per plant $(92.40 \mathrm{~g})$, followed by nitrogen $(75.55 \mathrm{~g})$ and potassium $(72.10 \mathrm{~g})$.
\end{abstract}

Key words: Ricinus communis L., growth, production, plant nutrition

\section{Adubação mineral com macronutrientes na mamoneira, linhagem UFRB 222}

RESUMO: O trabalho foi desenvolvido para avaliar o efeito da adubação mineral no crescimento e produção de sementes e óleo da mamoneira (Ricinus communis L.) linhagem UFRB 222, em experimento conduzido em estufa, pertencente ao Centro de Tecnologia e Recursos Naturais da Universidade Federal de Campina Grande. Utilizou-se delineamento em blocos ao acaso, com três repetições e 14 tratamentos, em distribuição de matriz baconiana, com as doses de referência 50:300:150 $\mathrm{kg} \mathrm{ha}^{-1}$ de $\mathrm{N}, \mathrm{P}_{2} \mathrm{O}_{5}$ e $\mathrm{K}_{2} \mathrm{O}$. Ao final do período experimental foram avaliados altura de planta, diâmetro caulinar, número de folhas, área foliar, número e peso total de sementes, número total de frutos e produção de óleo por planta. Em média, a dose de nitrogênio de $150 \mathrm{~kg} \mathrm{ha}^{-1}$ proporcionou valores adequados às variáveis de crescimento e de produção. Para o crescimento das plantas deve ser aplicado $300 \mathrm{~kg} \mathrm{ha}^{-1}$ de fósforo, uma vez que a diferença no aumento das variáveis de crescimento entre esta dose e as maiores doses estimadas pelas equações foram muito pequenas; para a produção da mamona, a melhor dose aplicada correspondeu a $600 \mathrm{~kg} \mathrm{ha}^{-1}$ de fósforo. A aplicação de potássio aumentou a área foliar, o número de sementes e a produção de óleo, e a melhor dose foi de $300 \mathrm{~kg} \mathrm{ha}^{-1}$. O fósforo foi o nutriente que promoveu a maior produção de óleo por planta $(92,40 \mathrm{~g})$, seguido por nitrogênio $(75,55 \mathrm{~g})$ e potássio $(72,10 \mathrm{~g})$.

Palavras-chave: Ricinus communis L., crescimento, produção, nutrição de plantas 


\section{INTRODUCTION}

Castor bean (Ricinus communis L.) is a species of the Euphorbiaceae family, an oilseed crop that has stood out in Northeast Brazil due to its high adaptability to adverse weather conditions and to soil and management conditions, and due to the multiplicity of industrial applications of castor bean oil (Marinho et al., 2010).

According to PROBIODIESEL (2002), Brazil has recovered the national production of castor bean compared to the previous harvests. However, due to several factors, such as lack of water, inadequate use of agricultural inputs and castor bean cultivation under low to medium technological level, according to Severino et al. (2006), productivity increases were small, disappointing several farmers, who abandoned castor bean cultivation.

Castor bean has been produced in some Brazilian states and many research studies about new lineage and/or cultivars still continue, especially at the Universidade Federal do Recôncavo $\mathrm{da}$ Bahia, where there is a germplasm bank of castor bean. One of these last lineages launched by the Universidade Federal do Recôncavo da Bahia was UFRB 222; however, the information on adequate fertilization recommendations for this lineage is not certain. It is known that plant nutrition is one of the main agronomic technologies used to increase crop productivity (Chaves et al., 2011), with nitrogen (N), phosphorus (P) and potassium $(\mathrm{K})$ elements, which are essential for growth and production of the castor bean.

The application of different fertilizers and doses, with or without irrigation, influences plant growth, seed production and, consequently, the production of oil of different castor bean cultivars, which respond to these factors differently. Although there is a recommendation of fertilization for the castor bean in general, there are no records in the literature on the nutritional requirements of each of these different cultivars and, consequently, differentiation as to their fertilization. Therefore, in order to know the behavior of a new lineage and/or cultivar, it is necessary to conduct several experiments. Thus, the objective of this research was to evaluate the growth and production of castor bean, lineage UFRB 222, under mineral fertilization.

\section{Material ANd Methods}

The experiment was carried out from July to October 2017 under greenhouse conditions, at the Centro de Tecnologia e Recursos Naturais of the Universidade Federal de Campina Grande (CTRN/UFCG), located in the municipality of Campina Grande, PB, Brazil, at local geographic coordinates $7^{\circ} 15^{\prime} 18^{\prime \prime} \mathrm{S}$, $35^{\circ} 52^{\prime} 28^{\prime \prime} \mathrm{W}$ and altitude of $550 \mathrm{~m}$.

The experimental design was completely randomized blocks with three repetitions and 14 treatments, distributed in a Baconian matrix scheme. In this matrix, one of the nutrients was supplied in varying amounts while the others were maintained at a reference level of 50, 300 and $150 \mathrm{~kg} \mathrm{ha}^{-1}$ of $\mathrm{N}, \mathrm{P}$ and $\mathrm{K}$, respectively, as shown in Table 1. Foliar fertilization was also performed in order to provide the macro- and micronutrients for the plants using a commercial product with the following composition: magnesium (5\%), sulfur (11\%), boron $(3.5 \%)$, calcium $(0.10 \%)$, iron $(20 \%)$, manganese $(1 \%)$, molybdenum
Table 1. Distribution of N, P, K doses in Baconian matrix

\begin{tabular}{|cccc|}
\hline Treatments & $\mathbf{N}$ & $\mathbf{P}$ & $\mathbf{K}$ \\
\cline { 2 - 4 } & & $\left(\mathbf{k g ~ h a}^{-1}\right)$ & \\
\hline 1 & 0 & 0 & 0 \\
3 & 0 & 300 & 150 \\
3 & 50 & 300 & 150 \\
5 & 100 & 300 & 150 \\
6 & 150 & 300 & 150 \\
7 & 200 & 300 & 150 \\
8 & 50 & 0 & 150 \\
9 & 50 & 300 & 0 \\
10 & 50 & 300 & 75 \\
11 & 50 & 300 & 225 \\
12 & 50 & 300 & 300 \\
13 & 50 & 150 & 150 \\
14 & 50 & 450 & 150 \\
\hline
\end{tabular}

$(0.10 \%)$ and zinc (5\%). For this, $2 \mathrm{~g}$ of this product were diluted in one liter and a half of water and applied twice.

Plants were grown in pots, which were filled, at the bottom, with a $2-\mathrm{kg}$ layer of crushed stone ( $\mathrm{n}^{\circ}$ zero) followed by 80 $\mathrm{kg}$ of soil material (properly pounded to break up clods and homogenized).

The soil used in the experiment was collected in the 0-20 $\mathrm{cm}$ layer of an Ultisol, from the municipality of Lagoa Seca, $\mathrm{PB}$, Brazil, and its physical and chemical characteristics were obtained according to the methodologies described by EMBRAPA (2011), presenting the following results: clay $=158.5$ $\mathrm{g} \mathrm{kg}^{-1}$, silt $=120.7 \mathrm{~g} \mathrm{~kg}^{-1}$ and sand $=720.8 \mathrm{~g} \mathrm{~kg}^{-1} ; \mathrm{pH}=5.75 ; \mathrm{EC}$ $(1: 2.5)=0.16 \mathrm{dS} \mathrm{m}^{-1} ; \mathrm{Ca}=1.56 \mathrm{cmol}_{\mathrm{c}} \mathrm{kg}^{-1} ; \mathrm{Mg}=1.18 \mathrm{cmol} \mathrm{kg}_{\mathrm{c}}^{-1}$; $\mathrm{Na}=0.06 \mathrm{cmol} \mathrm{kg}_{\mathrm{c}} ; \mathrm{K}=0.26 \mathrm{cmol}_{\mathrm{c}} \mathrm{kg}^{-1} ; \mathrm{H}=1.27 \mathrm{cmol}_{\mathrm{c}} \mathrm{kg}^{-1} ; \mathrm{P}$ $=4.9 \mathrm{mg} \mathrm{kg}^{-1} ; \mathrm{OM}=14.8 \mathrm{~g} \mathrm{~kg}^{-1}$.

Six seeds of the castor bean lineage UFRB 222 were planted in each pot, $2 \mathrm{~cm}$ deep and equidistantly distributed. Twenty, thirty and forty days after sowing (DAS), thinning was performed to leave only one plant per pot. After sowing, the soil was maintained at field capacity with daily irrigations, and the volume to be applied was determined according to the methodology previously cited by Lima et al. (2014).

Nitrogen fertilization, using urea, was applied twice, 50\% at 21 DAS and $50 \%$ at 30 DAS. Fertilizations with potassium and phosphorus were performed as topdressing, using single superphosphate and potassium chloride as a source of nutrients.

The growth of castor bean plants, lineage UFRB 222 was assessed at 120 DAS, based on the determination of plant height $(\mathrm{PH})$, stem diameter (SD), number of leaves (NL), leaf area (LA), total seed number (TSN), total seed weight (TSW), total fruit number (TFN) and oil production per plant (OP). $\mathrm{PH}$ was measured between the collar of the plant and the insertion of the apical meristem; SD was determined at $2 \mathrm{~cm}$ from the collar of the plants using a digital caliper; NL was quantified considering only leaves with $50 \%$ of photosynthetically active area and minimum length of $3 \mathrm{~cm}$; and LA was obtained according to the methodology of Severino et al. (2005):

$$
\mathrm{S}=\sum 0.26622 \times \mathrm{p}^{2.4248}
$$

where:

$\mathrm{S}$ - total leaf area, $\mathrm{cm}^{2}$; and,

$\mathrm{p} \quad$ - length of the main leaf vein, $\mathrm{cm}$. 
Collected data were subjected to analysis of variance by $\mathrm{F}$ test at $\mathrm{p} \leq 0.05$ and, when significant, linear and quadratic polynomial regression analysis was performed using the statistical software SISVAR (Ferreira, 2011). The contrasts between the control (absence of fertilizer) versus the doses of nutrients that did not significantly influence the variables analyzed were also performed.

\section{Results AND Discussion}

According to the analysis of variance summary (Table 2), all treatments had significant effect $(\mathrm{p} \leq 0.01)$ on the plant height $(\mathrm{PH})$, stem diameter $(\mathrm{SD})$, number of leaves $(\mathrm{NL})$, leaf area $(\mathrm{LA})$, total seed number (TSN), total seed weight (TSW), total number of fruits (TNF) and oil production per plant (OP) of the castor bean lineage UFRB 222.

Nitrogen, a primary macronutrient essential for plants, participates in the formation of proteins, amino acids and other compounds important in plant metabolism. Its absence blocks the synthesis of the hormone responsible for the growth of the plants, reducing their size and consequently reducing the economic production of the seeds (Mengel \& Kirkby, 2000). Therefore, the application of increasing doses of nitrogen influenced the characteristics related to plant growth, such as plant height, stem diameter, number of leaves per plant and leaf area (Table 2), contrary to what has been observed by Severino et al. (2006) and Marinho et al. (2010), working with the cultivar BRS Nordestina and IAC-Guarani, respectively. These authors did not observe a significant effect of nitrogen fertilization on the characteristics related to the growth of these cultivars. This is probably due to the fact that low doses of nitrogen were used in these experiments, since the highest nitrogen doses used were 100 and $130 \mathrm{~kg} \mathrm{ha}^{-1}$, respectively, that is, lower than the doses of the present study.

Biochemical processes in the plant, especially photosynthesis, are optimized by the great need for N (Marschner, 2002), which influences crop growth. In the present study, increasing doses of this element increased the behavior of castor bean growth characteristics (Figure 1). For example, plant height linearly (Figure $1 \mathrm{~A}$ ) increased by $10.21 \%$ as the $\mathrm{N}$ dose increased from 50 (reference dose) to $200 \mathrm{~kg} \mathrm{ha}^{-1}$ (highest dose), corroborating with Araujo et al. (2009), who observed the same effect of nitrogen on plant height. That is, there was a $7.43 \%$ increase in plant height of BRS Nordestina cultivar as a result of increasing doses of $\mathrm{N}$ from 40 (reference dose) to $200 \mathrm{~kg} \mathrm{ha}^{-1}$, although there was no significant effect, corroborating with other authors (Severino et al., 2006; Ribeiro et al., 2009).

The evolution of the stem diameter of the castor bean plants submitted to the different doses of nitrogen showed a quadratic effect resulting in an increase of $2.87 \%$, due to the increase of the dose from 50 (reference dose) to $114.4 \mathrm{~kg} \mathrm{ha}^{-1}$ (dose corresponding to the largest diameter) (Figure 1B). This increase was lower than $12.23 \%$, observed by Araujo et al. (2009). However, the highest stem diameter observed in the present study, $26.78 \mathrm{~mm}$, with the $\mathrm{N}$ dose of $114.4 \mathrm{~kg} \mathrm{ha}^{-1}$, was similar to that observed by Araujo et al. (2009).

Number of leaves increased in a quadratic manner by $43.88 \%$, ranging from the $\mathrm{N}$ dose of 50 to $157.62 \mathrm{~kg} \mathrm{ha}^{-1}$ (Figure 1C). Similarly, the leaf area had a quadratic behavior (Figure 1D), reaching a maximum of $1.78 \mathrm{~m}^{2}$, corresponding to $144 \mathrm{~kg} \mathrm{ha}^{-1}$ of $\mathrm{N}$; thus, there was an increase of $32.84 \%$ in leaf area compared to the reference dose of $50 \mathrm{~kg} \mathrm{ha}^{-1}$. According to Araujo et al. (2009), the leaf area of the plants submitted to increasing doses of $\mathrm{N}$ ranging from 40 to $160 \mathrm{~kg} \mathrm{ha}^{-1}$ increased by $47.49 \%$. The increase in the number of leaves and consequently in leaf area due to the application of nitrogen is of great importance, since there is a close relationship between leaf area and photosynthesis and, consequently, this process influences the development of the plants.

Production variables such as total number of seeds, total weight of seeds, total number of fruits and production of oil per plant were also influenced by the applied nitrogen rates (Table 1). However, increasing doses of nitrogen in the castor bean cultivar IAC-Guarani did not influence the whole plant production variables, as occurred in the present study, but influenced these variables only from the second raceme (Marinho et al., 2010).

Table 2. Summary of analysis of variance for plant height (PH), stem diameter (SD), number of leaves (NL), leaf area (LA), total seed number (TSN), total seed weight (TSW), total number of fruits (TNF) and oil production per plant (OP) analyzed at 120 DAS, as a function of different doses of nitrogen, phosphorus and potassium in the cultivation of castor bean lineage UFRB 222

\begin{tabular}{|c|c|c|c|c|c|c|c|c|c|}
\hline \multirow{2}{*}{ Source of variation } & \multirow{2}{*}{$\mathbf{D F}$} & \multicolumn{8}{|c|}{ Mean square } \\
\hline & & PH & SD & NL & LA & TSN & TSW & TNF & OP \\
\hline Treatments & 13 & $* *$ & $\star \star$ & $* *$ & $* *$ & $* *$ & $* *$ & $* *$ & $* *$ \\
\hline $\mathrm{N}$ & 4 & ** & $\star \star$ & $\star \star$ & $\star \star$ & $\star \star$ & $\hbar \star$ & ** & ** \\
\hline Linear & 1 & ** & ns & ** & ** & ** & ** & ** & ** \\
\hline Quadratic & 1 & ns & ** & $\star \star *$ & ** & * & * & * & * \\
\hline Deviation & 2 & 5.39 & 1.04 & 13.3 & 0.047 & 64.1 & 341.8 & 64.1 & 114.9 \\
\hline $\mathrm{P}$ & 4 & $\star \star$ & $\star \star$ & $\star \star *$ & $\star \star$ & $\star \star *$ & $\star \star$ & $\star \star *$ & $\star \star$ \\
\hline Linear & 1 & ** & ** & ** & ** & ** & ** & $\star *$ & ** \\
\hline Quadratic & 1 & ** & ** & * & ** & $* *$ & ** & ** & ns \\
\hline Deviation & 2 & 5.39 & 1.04 & 13.3 & 0.047 & 64.1 & 341.8 & 64.1 & 114.9 \\
\hline $\mathrm{K}$ & 4 & $* *$ & $\star \star *$ & $\mathrm{~ns}$ & ns & $\star \star *$ & $\mathrm{~ns}$ & ns & * \\
\hline Linear & 1 & ** & ns & ns & * & ** & ns & ns & ** \\
\hline Quadratic & 1 & ns & ns & ns & ns & ns & ns & ns & ns \\
\hline Deviation & 2 & 5.39 & 1.04 & 13.3 & 0.047 & 64.1 & 341.8 & 64.1 & 114.9 \\
\hline $\mathrm{PF} \times \mathrm{AF}^{\prime}$ & 1 & ** & ** & ** & $\star \star$ & $\star \star$ & $\star *$ & ** & $\star \star$ \\
\hline Residual & 28 & 4.51 & 1.71 & 3.27 & 0.057 & 73.6 & 315.7 & 73.58 & 96.92 \\
\hline CV (\%) & $\%$ & 3.31 & 5.34 & 10.21 & 18.74 & 4.34 & 15.26 & 14.69 & 16.7 \\
\hline
\end{tabular}

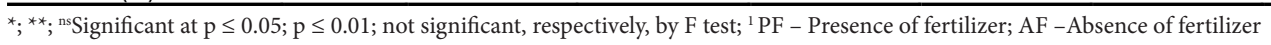



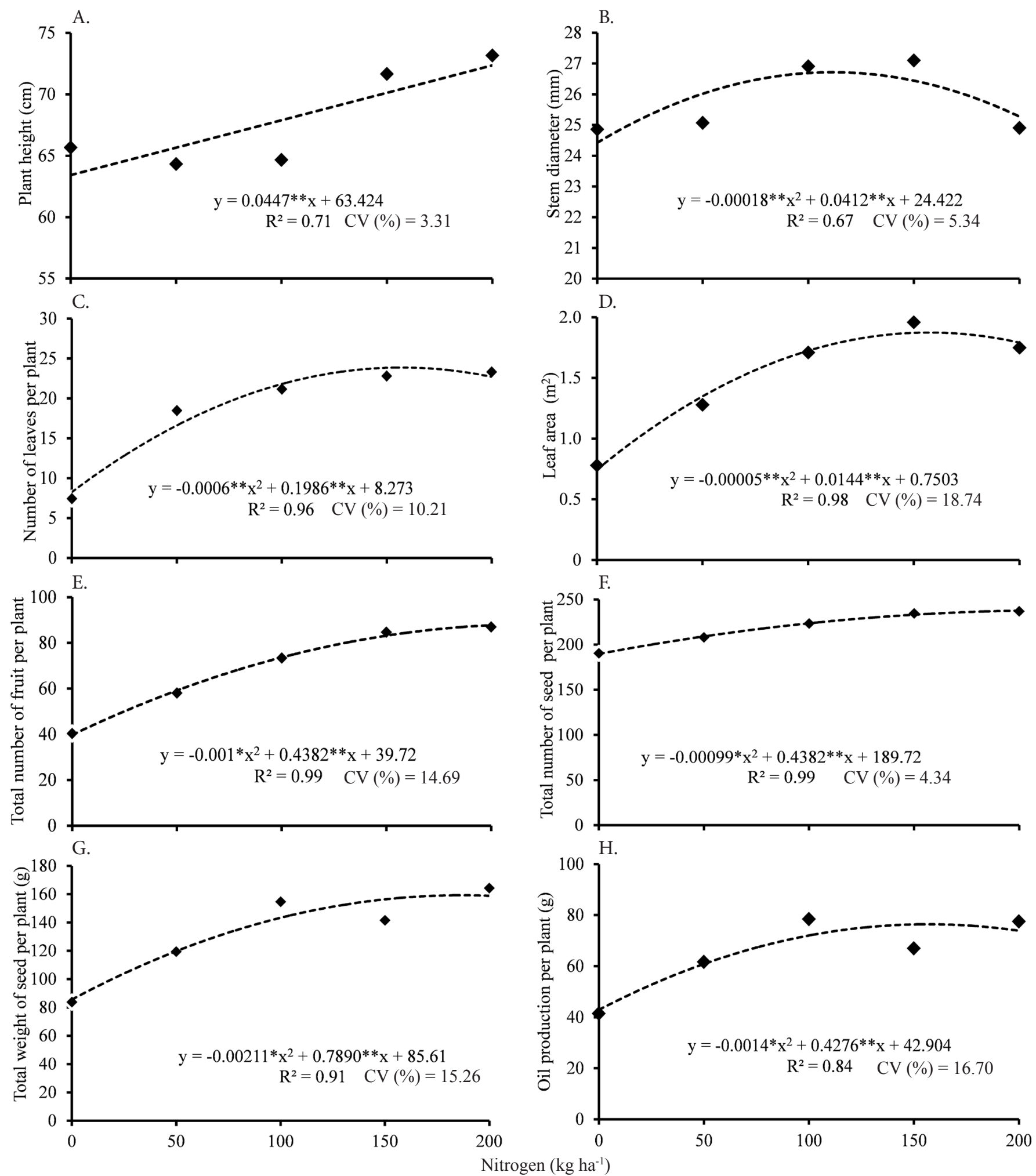

$*$; **Significant at $\mathrm{p} \leq 0.05$ and $\mathrm{p} \leq 0.01$, respectively, by $\mathrm{F}$ test

Figure 1. Plant height (A), stem diameter (B), number of leaves (C), leaf area (D), total number of fruits (E), total number of seeds $(\mathrm{F})$, total weight of seed $(\mathrm{g})(\mathrm{G})$ and oil production $(\mathrm{g})(\mathrm{H})$ of lineage UFRB 222 castor bean under different doses of nitrogen at 120 days after sowing

Nitrogen fertilization had a significant effect on the number of fruits per plant, which increased quadratically as a function of the doses applied in the crop (Figure 1E), corroborating with Mesquita et al. $(2011,2012 a)$. These authors, testing NPK doses in cultivars BRS Nordestina and BRS Paraguaçu, reported a significant response in the number of fruits per plant only in fertilization with $\mathrm{N}$ (200 $\left.\mathrm{kg} \mathrm{ha}^{-1}\right)$, obtaining 43.42 and 39.75 fruits, respectively. According to Silva et al. (2013), the number of fruits was not significantly affected by fertilization in the cultivar Al Guarany 2002, which produced 121 fruits with soil application of $0,40,80$ and $160 \mathrm{~kg} \mathrm{ha}^{-1}$ of nitrogen.

However, the lineage UFRB 222 fertilized with 50 (reference dose) and $200 \mathrm{~kg} \mathrm{ha}^{-1} \mathrm{~N}$ produced 59.16 and 87.76 fruits, respectively, with a $48.34 \%$ increase between these doses, i.e., 
these productions were higher than those found by Mesquita et al. $(2011 ; 2012 a)$.

Likewise, the number of seeds per plant increased quadratically (Figure 1F) and the highest nitrogen dose, 200 $\mathrm{kg} \mathrm{ha}^{-1}$, led to the production of 238.21 seeds, that is, $13.89 \%$ more than the number obtained with the reference dose of 50 $\mathrm{kg} \mathrm{ha}^{-1}$. According to Mesquita et al. (2012a, b), the application of nitrogen in the castor bean cultivars BRS Paraguaçu and BRS Nordestina had a significant effect on seed number, producing 117.33 and 129.42 seeds with $200 \mathrm{~kg} \mathrm{ha}^{-1} \mathrm{~N}$, respectively.

In relation to seed weight per plant (Figure $1 \mathrm{G}$ ), nitrogen fertilization caused a quadratic effect, with a maximum weight of $159.37 \mathrm{~g}$ at the dose of $186.97 \mathrm{~kg} \mathrm{ha}^{-1}$, greater than the values of $63.23 \mathrm{~g}$ observed by Ribeiro et al. (2009) and higher than the values of 100.19 and $151.51 \mathrm{~g}$ observed by Mesquita et al. (2012a,b) in the BRS Nordestina and BRS Paraguaçu cultivars, respectively. The weight of 100 seeds per plant, that is, for two racemes, in relation to nitrogen treatments, ranged from 45.12 $\mathrm{g}\left(0 \mathrm{~kg} \mathrm{ha}^{-1}\right)$ to $66.88 \mathrm{~g}\left(200 \mathrm{~kg} \mathrm{ha}^{-1}\right)$. These weights, calculated through the equations presented in Figures $1 \mathrm{~F}$ and $\mathrm{G}$, are smaller than 77.92 g, observed by Mesquita et al. (2011) working with BRS Nordestina and by Marinho et al. (2010), working with the same treatments, but with the cultivar IAC-Guarani cultivated in the field. According to Silva et al. (2013), increasing doses of nitrogen in the cultivar Al Guarany 2002 did not promote significant effect on the mean weight of the seeds.

Nitrogen fertilization showed quadratic effect, with maximum oil content, $75.55 \mathrm{~g}$, at the dose of $152.71 \mathrm{~kg} \mathrm{ha}^{-1}$, that is, between this dose and zero dose, there was an increase of $76.09 \%$ in oil content (Figure $1 \mathrm{H}$ ). However, between the reference dose of $50 \mathrm{~kg} \mathrm{ha}^{-1}(60.78 \mathrm{~g}$ oil) and the dose of 152.71 $\mathrm{kg} \mathrm{ha}^{-1}$ of $\mathrm{N}$, there was only a $24.30 \%$ increase in oil content. This consistent increase in oil content in the seeds of the lineage UFRB 222 in response to the nitrogen doses was not observed by Severino et al. (2006), who applied increasing doses from zero to $100 \mathrm{~kg} \mathrm{ha}^{-1} \mathrm{~N}$ in castor bean, cultivar BRS Nordestina.

The higher nitrogen doses calculated by the equations that represent the behavior of this chemical element in the growth and production variables can be observed above $100 \mathrm{~kg} \mathrm{ha}^{-1}$; however, according to the small percentages of increase of these variables with the increasing $\mathrm{N}$ doses from 100 to $200 \mathrm{~kg} \mathrm{ha}^{-1}$, it can be said that, economically, dose of $100 \mathrm{~kg} \mathrm{ha}^{-1}$ would be recommended.

Phosphorus, a macronutrient essential for plants, is part of the plant structure and influences plant physiology and metabolism, such as energy transfer, nucleic acid synthesis, enzyme activity regulator, respiration, photosynthesis (Harger et al., 2007). For castor bean, several studies confirm the effect of P (Almeida Junior et al., 2009) on productivity (Oliveira et al., 2010) and oil content (Severino et al., 2006), but these effects need to be confirmed in other environments and with other genotypes (Silva et al., 2012). Evaluating the behavior of the lineage UFRB 222 as a function of phosphate fertilization, it was observed that increasing doses of this element influenced the characteristics related to plant growth, such as plant height, stem diameter, number of leaves per plant and leaf area (Table 2), contrary to what has been observed by Ribeiro et al. (2009) and Souza et al. (2009) working with the cultivars BRS Paraguaçu and
BRS Nordestina, respectively. According to Araujo et al. (2009), phosphorus influenced plant height and did not influence stem diameter and leaf area, corroborating with Severino et al. (2006).

Although phosphorus influenced plant height, between the doses of 300 (reference) and $422.27 \mathrm{~kg} \mathrm{ha}^{-1}$ (highest height reached), height increased only by $2.43 \%$ (Figure $2 \mathrm{~A}$ ). Severino et al. (2006) did not observe a significant effect of phosphate fertilization on plant height. The stem diameter varied quadratically, presenting the highest value, $29.10 \mathrm{~mm}$, at the dose of $487.5 \mathrm{~kg} \mathrm{ha}^{-1}$ (Figure 2B). Comparing this value with that observed with the reference dose of $300 \mathrm{~kg} \mathrm{ha}^{-1}(26.99$ $\mathrm{mm}$ ), there was an increase of $7.82 \%$.

Leaf expansion is closely related to epidermal cell expansion and internal phosphorus concentration in plant tissue (Marschner, 2002). Therefore, the phosphate fertilization caused a quadratic effect on the number of leaves (Figure 2C) and the leaf area per plant (Figure 2D), respectively, causing an increase in the number of leaves of $10.14 \%$ from the reference dose of 300 $\mathrm{kg} \mathrm{ha}^{-1}$, to the dose of $495 \mathrm{~kg} \mathrm{ha}^{-1}$, where the highest number of leaves was observed, 20.65. Figure 2D presented an increase in leaf area of $15.89 \%$ comparing the value found at the reference dose of $300 \mathrm{~kg} \mathrm{ha}^{-1}$, to the largest leaf area observed, $1.61 \mathrm{~m}^{2}$, at the dose of $510 \mathrm{~kg} \mathrm{ha}^{-1}$. However, there was an increase of $422.79 \%$ in the leaf area of the plants fertilized with $510 \mathrm{~kg} \mathrm{ha}^{-1}$ in comparison to the plants not fertilized with phosphorus, corroborating with Almeida Junior et al. (2009), who observed an increase of $268 \%$ in the leaf area of the castor bean cultivar BRS Nordestina. Silva et al. (2012) also observed a significant effect on the leaf area of this same cultivar as a function of phosphorus application. On the other hand, Souza et al. (2009), using phosphorus doses from 0 to $320 \mathrm{~kg} \mathrm{ha}^{-1}$ of $\mathrm{P}_{2} \mathrm{O}_{5}$, did not observe the effect of phosphate fertilization on the leaf area, but verified that the highest averages were obtained by the higher doses.

In relation to the total number of fruits per plant (two racemes) (Figure 2E), the phosphate fertilization caused a quadratic effect, with maximum number of 78.90 fruits, at $581.33 \mathrm{~kg} \mathrm{ha}^{-1}$. Moreira et al. (2012) reported average values of 27.9 fruits per raceme, in a study with the castor bean cultivar IAC Guarani as a function of phosphorus and boron, while several types of combination of fertilizations with soluble and natural phosphate had a significant effect on the number of fruits of the cultivar BRS Paraguaçu, which produced 142 fruits per plant and on average, 28.4 fruits in each raceme (Silveira et al., 2015). However, the different doses of phosphate fertilizer did not promote a significant effect on the number of fruits per plant in the cultivar Al Guarany 2002, producing 105 seeds with all treatments (Silva et al., 2013).

The total number and weight of the seeds were significantly and quadratically influenced by the doses of phosphorus (Figures 2F and G), contrary to what Silva et al. (2013) observed. According to these authors, increasing doses of phosphorus in the cultivar Al Guarany 2002 did not promote significant effect on the average weight of the seeds. The total seed number corresponding to the highest dose of phosphorus, $581.33 \mathrm{~kg}$ $\mathrm{ha}^{-1}$, was 219.9 and the mean weight of 100 seeds was $71.04 \mathrm{~g}$; however, with the dose of $90 \mathrm{~kg} \mathrm{ha}^{-1}, 100$ seeds weighed around $41.81 \mathrm{~g}$, that is, lower than the $70 \mathrm{~g}$ obtained by Silveira et al. 

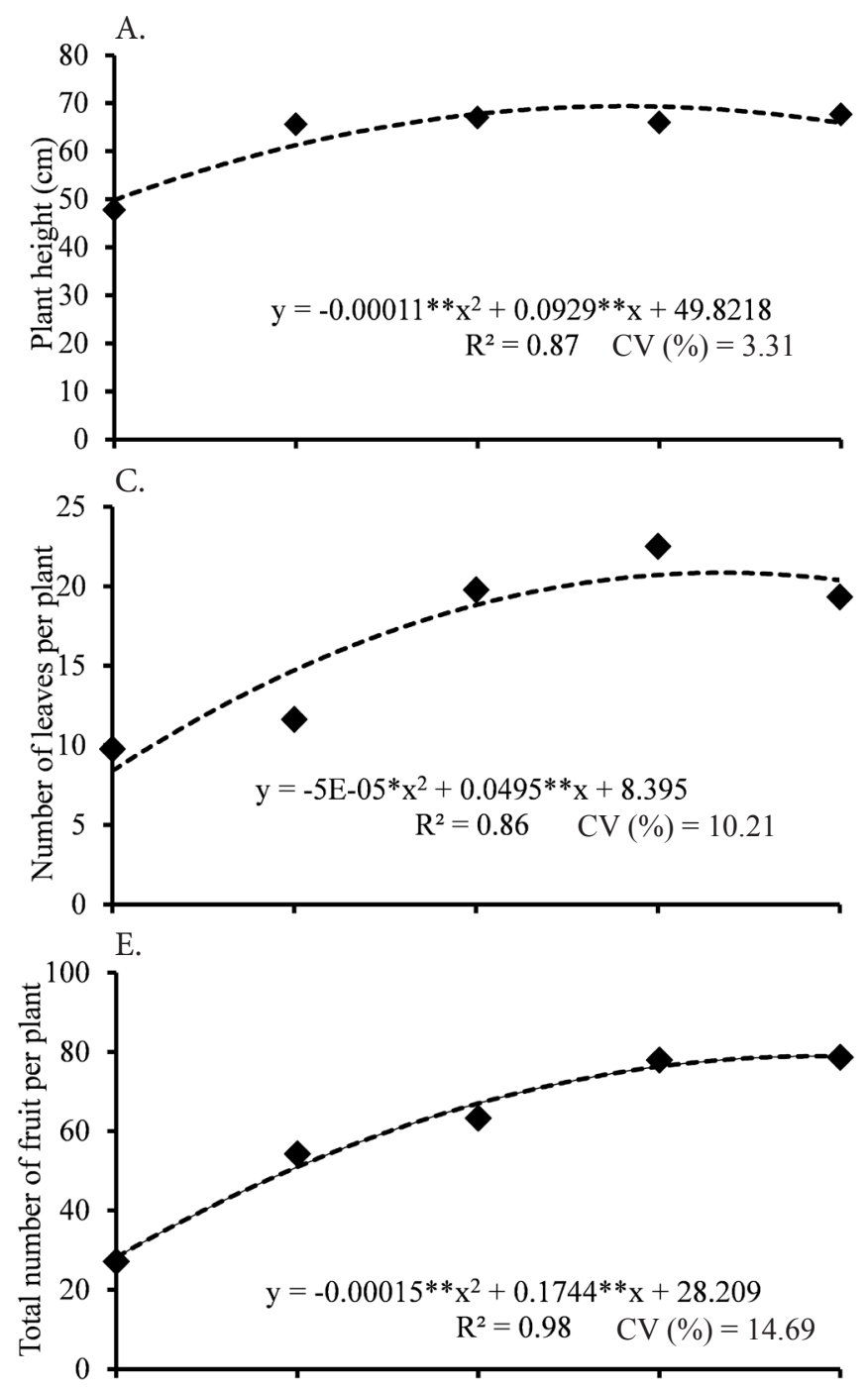

G.

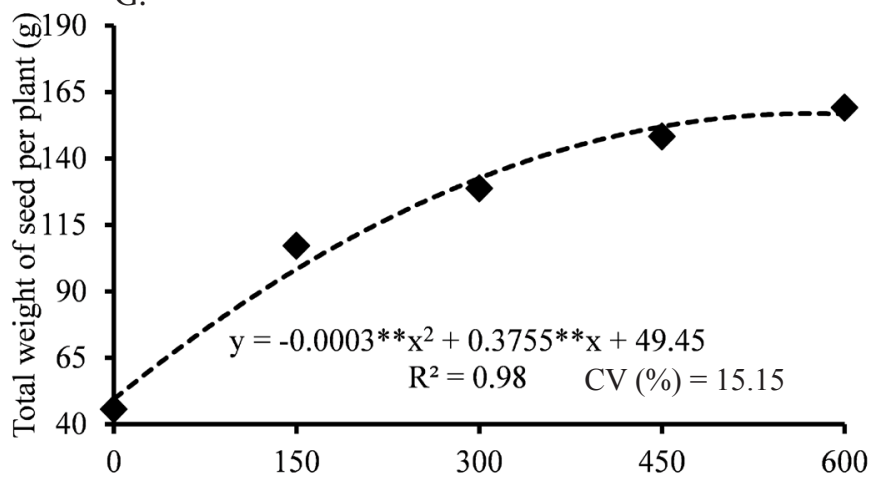

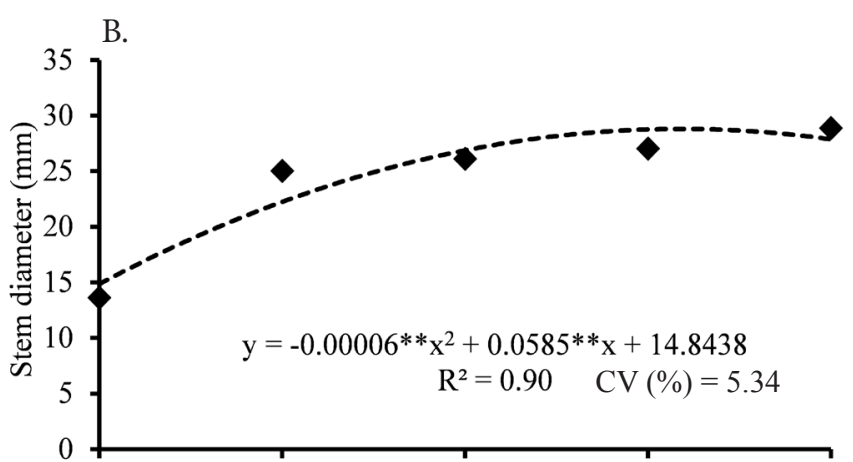

D.
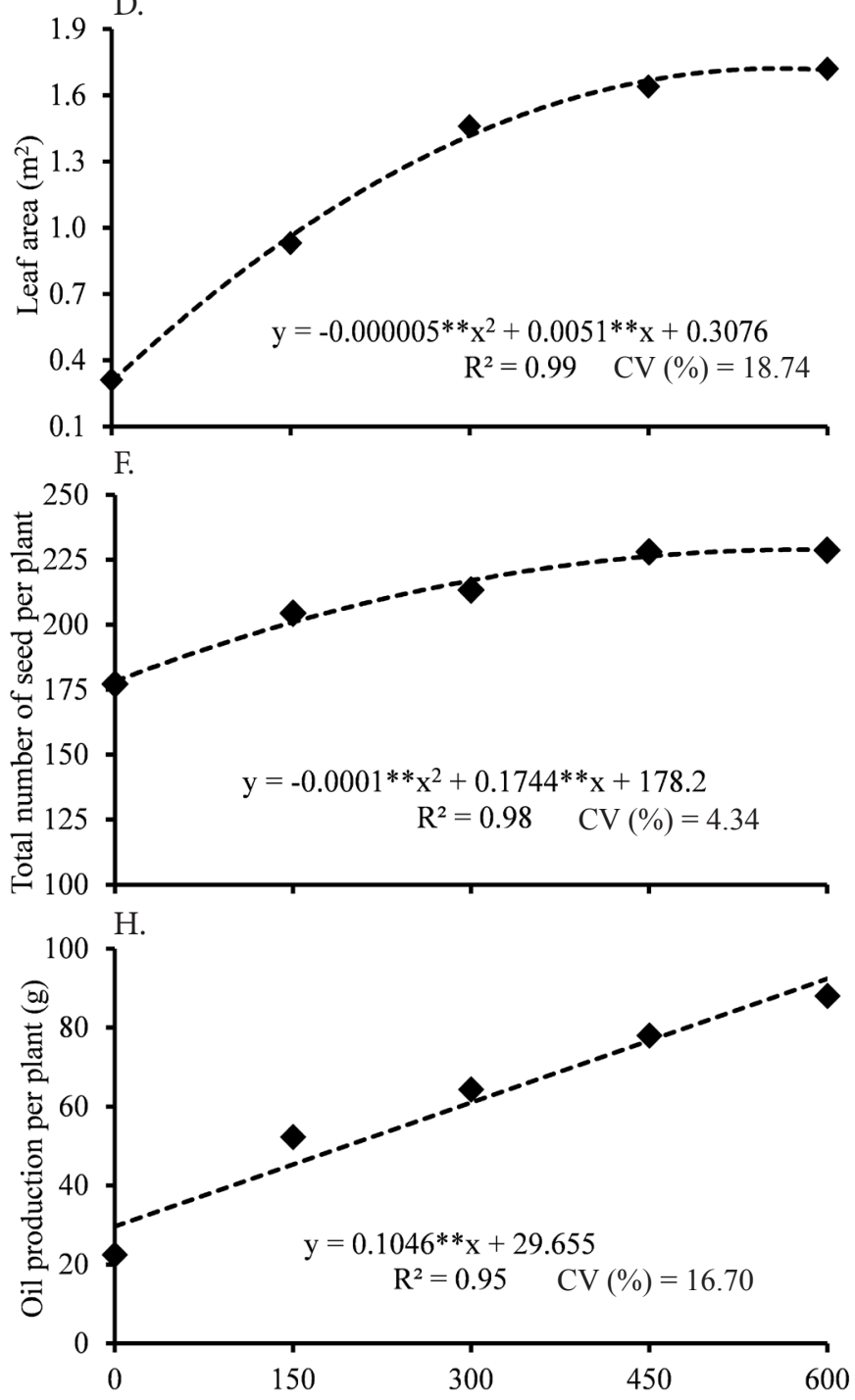

Phosphorus $\left(\mathrm{kg} \mathrm{ha}^{-1}\right)$

*; **- Significant at $\mathrm{p} \leq 0.05$ and $\mathrm{p} \leq 0.01$, respectively, by $\mathrm{F}$ test

Figure 2. Plant height (A), stem diameter (B), number of leaves (C), leaf area (D), total number of fruits (E), total number of seeds $(F)$, total weight of seed $(\mathrm{G})$ and oil production $(\mathrm{H})$ of lineage UFRB 222 castor bean under different doses of phosphorus at 120 days after sowing

(2015) using the same dose of phosphorus, and similar to the 47 $\mathrm{g}$ found by Corrêa et al. (2006) while evaluating the behavior of castor bean cultivars in different cropping systems. Among the doses of $\mathrm{P}$ used by Ribeiro et al. (2009), the one corresponding to $120 \mathrm{~kg} \mathrm{ha}^{-1} \mathrm{P}_{2} \mathrm{O}_{5}$ promoted the highest seed yield (43.07 $\mathrm{g}$ ).

A consistent linear increase of the oil content in the seeds was observed in response to the increase in phosphorus doses (Figure 2H). Between dose of 300 (reference dose) and $600 \mathrm{~kg} \mathrm{ha}^{-1}$ of $\mathrm{P}$ (highest dose), the oil content increased by $51.41 \%$, corroborating with Severino et al. (2006). Between the doses of 300 (reference dose) and $600 \mathrm{~kg} \mathrm{ha}^{-1}$ of P (highest dose), the oil content produced, 61.03 and $92.4 \mathrm{~g}$, respectively, increased by $51.41 \%$, corroborating Severino et al. (2006).

Potassium is important in the productivity of the castor bean, because it activates more than 60 enzymes (Peuke et al., 2002). Among the growth variables, only the height and leaf area of the plants was influenced by potassic fertilization (Table 2 ), and these variables were, respectively, linearly reduced and 
increased with increasing doses of potassium (Figures 3B and D). This behavior was also observed in the plants of the cultivar BRS Nordestina even though it was not a significant reduction (Severino et al., 2006). According to Araujo et al. (2009) and Ribeiro et al. (2009), increasing doses of potassium did not influence the height of the castor bean cultivars BRS Nordestina and BRS Paraguaçu, respectively.

Based on the contrasts of means obtained for all the plant growth and production variables (Table 2), significant effect

A.

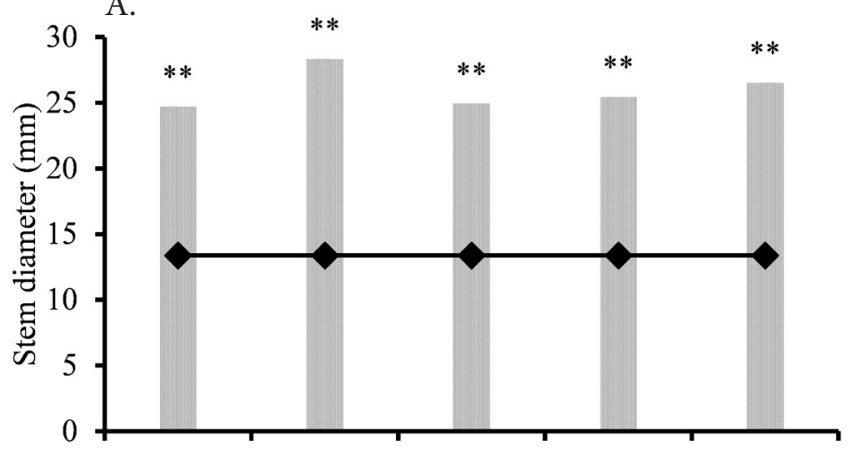

C.

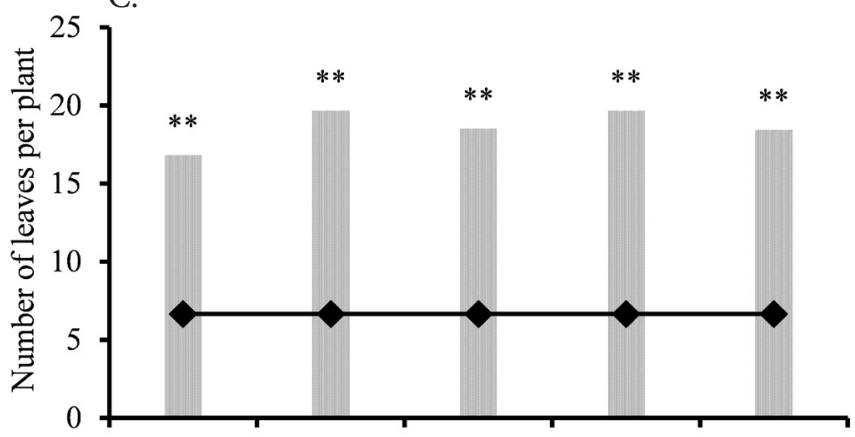

E.

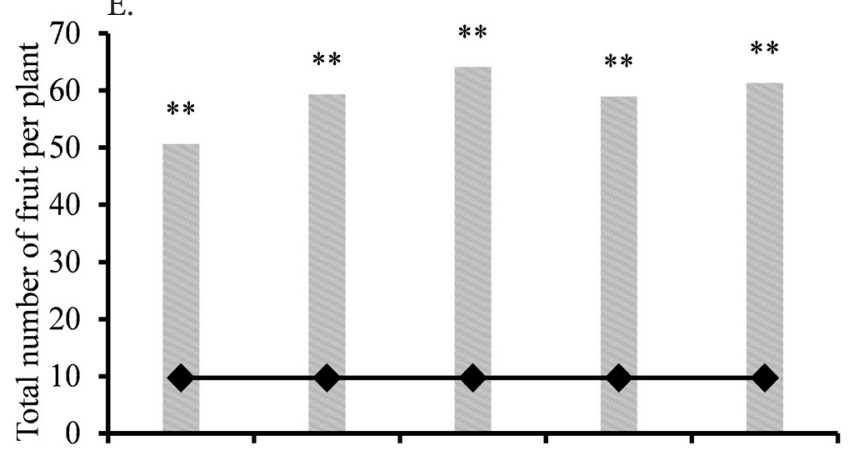

$\mathrm{G}$.

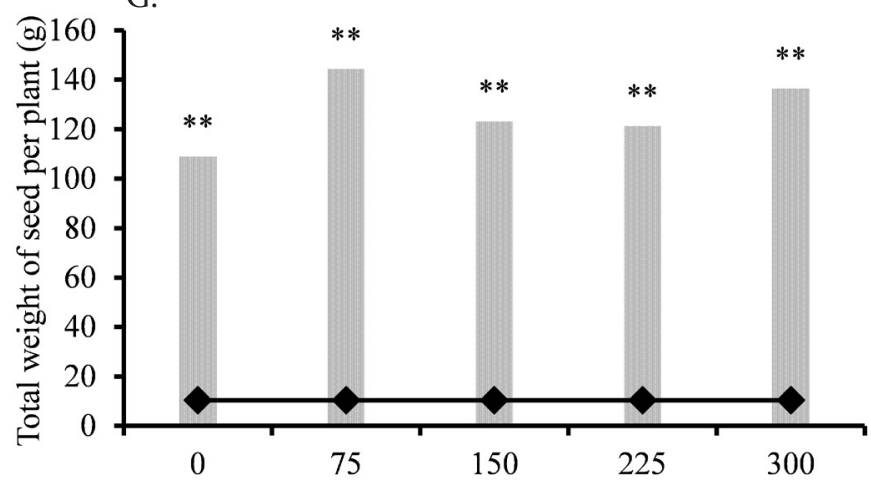

occurred in the comparison between fertilized plants and non-fertilized plants. This showed that the productivity of the fertilized crop was more intense when compared to the absence of fertilization. The results obtained demonstrate the need for balanced fertilization to optimize the productivity and oil production of this crop.

The different doses of potassium at 120 DAS did not influence the stem diameter and number of leaves of lineage UFRB 222 castor bean, corroborating with Araujo et al. (2009) and Ribeiro

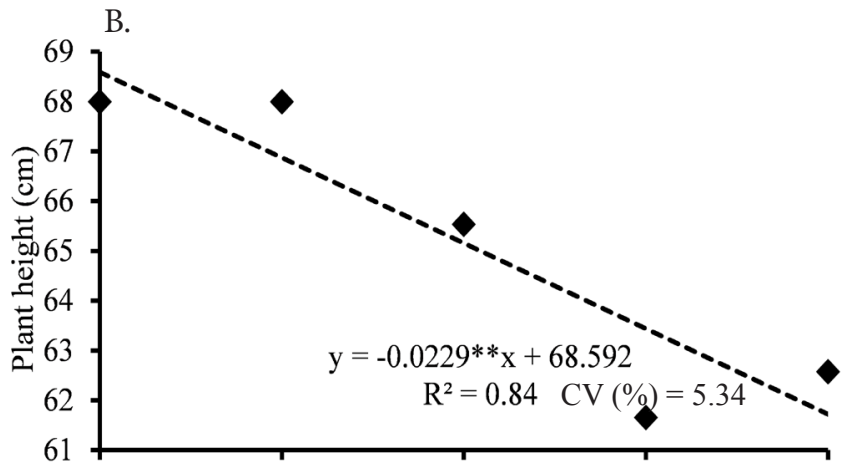

D.
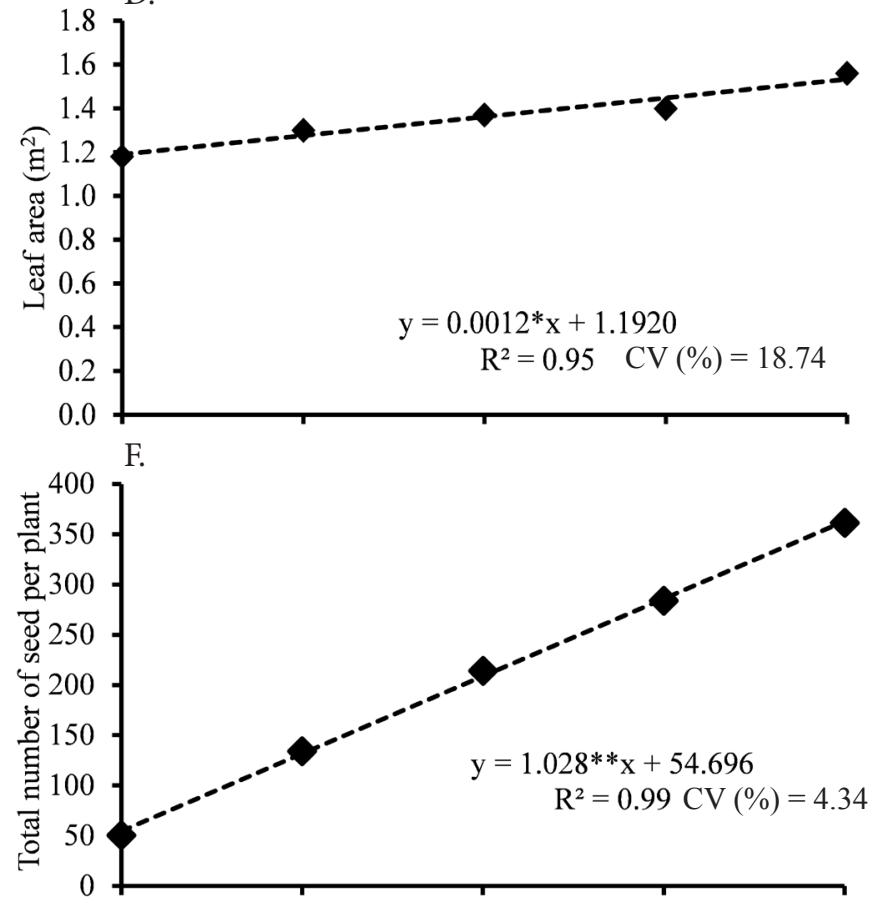

$\mathrm{H}$.

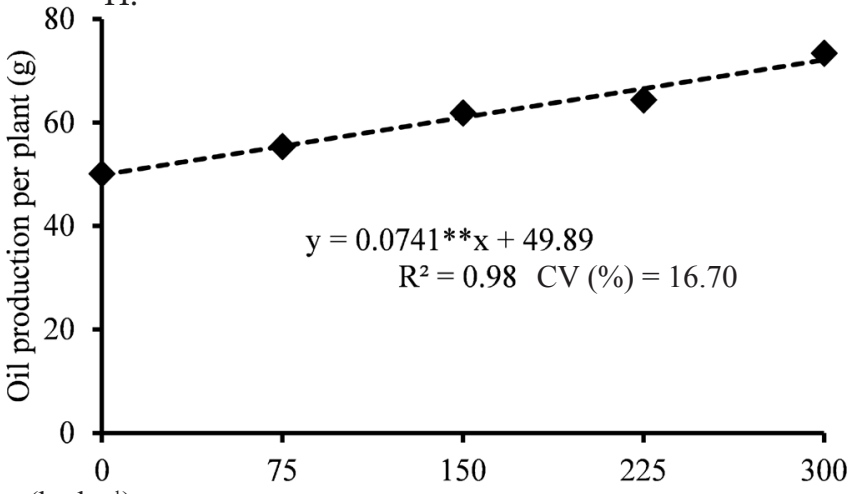

*; **- Significant at $\mathrm{p} \leq 0.05$ and $\mathrm{p} \leq 0.01$, respectively, by F test

Figure 3. Stem diameter (A), plant height (B), number of leaves (C), leaf area (D) total number of fruits (E), total number of seeds $(\mathrm{F})$, total weight of seed $(\mathrm{G})$ and oil production $(\mathrm{H})$ of lineage UFRB 222 castor bean under different doses of potassium at 120 days after sowing. Horizontal bar represents the contrast between the control (absence of fertilizer) versus potassium doses 
et al. (2009), so the results of these variables were contrasted with those obtained from the non-fertilized plants as can be seen from Figures $3 \mathrm{~A}$ and $\mathrm{C}$, respectively. Based on these contrasts, there were increases of 111.5 and $194.9 \%$ in the stem diameter and number of leaves, respectively, of the fertilized plants. According to Severino et al. (2006), increasing doses of potassium did not influence the stem diameter of the BRS Nordestina castor bean; however, fertilization was significant compared to the non-fertilized plants.

The number of fruits per plant was not influenced by potassium fertilization, and around 64.14 fruits were produced with $150 \mathrm{~kg} \mathrm{ha}^{-1}$ (Figure 3E). However, in the cultivar Al Guarany 2002, the number of fruits per plant decreased significantly as a function of increasing doses of potassium (Silva et al., 2013). Similar results were verified by Chaves \& Araújo (2011), which showed a reduction in the number of fruits of the BRS Nordestina castor bean from 40 to $200 \mathrm{~kg} \mathrm{ha}^{-1}$ of $\mathrm{K}_{2} \mathrm{O}$.

Likewise, the weight of the seeds per plant of the lineage UFRB 222 was not influenced by potassium fertilization (Table 2), corroborating with Silva et al. (2013). At the dose of $75 \mathrm{~kg}$ $\mathrm{ha}^{-1}$, the crop produced $144.36 \mathrm{~g}$ of seeds; this was the highest production achieved (Figure $3 \mathrm{G}$ ).

According to the contrast, the number of fruits and the weight of the seeds in the fertilized plants increased by 561.2 and $1288.1 \%$, respectively, in comparison to the plants not fertilized (Figures $3 \mathrm{E}$ and $\mathrm{G}$ ). This shows the importance of fertilization in the castor bean crop.

Increasing amounts of potassium linearly influenced the number of seeds (Figure 3F) and the production of oil per plant (Figure 3H), disagreeing with Severino et al. (2006). The highest number of seeds, 363.1, and the highest production of oil, $72.1 \mathrm{~g}$, were produced with the highest dose of potassium, $300 \mathrm{~kg} \mathrm{ha}^{-1}$; thus, there were increases of 73.82 and $18.18 \%$, respectively, in comparison to the reference dose of $150 \mathrm{~kg} \mathrm{ha}^{-1}$.

In general, the behavior of the new lineage of castor bean UFRB 222 in relation to mineral fertilization was similar to the behavior of other cultivars. The application of nitrogen, phosphorus and potassium influenced in one way or another the growth of the plant and the production variables.

\section{Conclusions}

1. On average, the nitrogen dose of $150 \mathrm{~kg} \mathrm{ha}^{-1}$, led to adequate values of growth and yield variables.

2. For plant growth, $300 \mathrm{~kg} \mathrm{ha}^{-1}$ of phosphorus should be applied for castor bean production, the best applied dose is $600 \mathrm{~kg} \mathrm{ha}^{-1}$.

3. The application of potassium increased leaf area, number of seeds and production of oil, and the best dose was $300 \mathrm{~kg} \mathrm{ha}^{-1}$.

4. Phosphorus was the nutrient that promoted the highest production of oil per plant ( $92.40 \mathrm{~g})$, followed by nitrogen (75.55 $\mathrm{g})$ and potassium $(72.10 \mathrm{~g})$.

\section{Literature Cited}

Almeida Junior, A. B. de; Oliveira, F. A. de; Medeiros, J. F. de; Oliveira, M. K. T. de; Linhares, P. C. F. Efeito de doses de fósforo no desenvolvimento inicial da mamoneira. Revista Caatinga, v.22, p.217-221, 2009.
Araujo, D. L. de; Chaves, L. H. G.; Mesquita, E. F. de; França, C. P. Crescimento da mamoneira cultivar BRS-149 Nordestina adubada com nitrogênio, fósforo e potássio. Engenharia Ambiental: Pesquisa e Tecnologia, v.6, p.685-702, 2009.

Chaves, L. H. G.; Araújo, D. L. de. Fitomassa e produção da mamoneira BRS Nordestina adubada com NPK. Engenharia Ambiental: Pesquisa e Tecnologia, v.8, p.222-231, 2011.

Chaves, L. H. G.; Gheyi, H. R.; Ribeiro, S. Consumo de água e eficiência do uso para cultivar de mamona Paraguaçu submetida à fertilização nitrogenada. Engenharia Ambiental: Pesquisa e Tecnologia, v.8, p.126-133, 2011.

Corrêa, M. L. P.; Távora, F. J. A. F.; Pitombeira, J. B. Comportamento de cultivares de mamona em sistemas de cultivo isolados e consorciados com caupi e sorgo granífero. Revista Ciência Agronômica, v.37, p.200-207, 2006.

EMBRAPA - Empresa Brasileira de Pesquisa Agropecuária. Manual de métodos de análise de solo. 2.ed. Rio de Janeiro: Embrapa Solos, 2011. 230p.

Ferreira, D. F. Sisvar: A computer statistical analysis system. Ciência e Agrotecnologia, v.35, p.1039-1042, 2011. https://doi.org/10.1590/ S1413-70542011000600001

Harger, N.; Brito, O. R.; Ralisch, R.; Ortiz, F. R.; Watanabe, T. S. Avaliação de fontes e doses de fósforo no crescimento inicial do milho. Semina: Ciências Agrárias, v.28, p.39-44, 2007. https://doi. org/10.5433/1679-0359.2007v28n1p39

Lima, G. S. de; Nobre, R. G.; Gheyi, H. R.; Soares, L. A. dos A.; Silva, S. da S. Respostas morfofisiológicas da mamoneira, em função da salinidade da água de irrigação e adubação nitrogenada. Irriga, v.19, p.130-136, 2014. https://doi.org/10.15809/irriga.2014v19n1p130

Marinho, A. B.; Moreira, L. G.; Viana, T. V. A.; Albuquerque, A. H. P.; Oliveira, C. W.; Azevedo, B. M. Influência da fertirrigação da nitrogenada na produtividade da cultura da mamoneira. Revista Brasileira de Agricultura Irrigada, v.4, p.31-42, 2010. https://doi. org/10.7127/rbai.v4n100024

Marschner, H. Mineral nutrition of higher plants. San Diego: Academic Press, 2002. 889p.

Mengel, K.; Kirkby, E. A. Princípios de nutrición vegetal. Basel: International Potash Institute, 2000. 692p.

Mesquita, E. F.; Chaves, L. H. G.; Guerra, H. O. C. Fitomassa e componentes da produção da mamona fertilizada com nitrogênio, fósforo e potássio. Agrarian, v.4, p.344-351, 2011.

Mesquita, E. F.; Chaves, L. H. G.; Guerra, H. O. C. Fitomassa e componentes da produção da mamona cultivar Paraguaçu adubada com nitrogênio, fósforo e potássio. Engenharia Ambiental: Pesquisa e Tecnologia, v.9, p.94-104, 2012a.

Mesquita, E. F.; Chaves, L. H. G.; Guerra, H. O. C.; Lacerda, R. D. Crescimento e produção de duas cultivares de mamoneira sob fertilização NPK. Revista Caatinga, v.25, p.35-43, 2012 b.

Moreira, M. A.; Alves, J. M.; Oliveira, A. B. de; Medeiros, F. A. de. Crescimento e produção da mamoneira em função de fósforo e boro. Global Science and Technology, v.5, p.98-108, 2012.

Oliveira, J. P. M. de; Scivittaro, W. B.; Castilhos, R. M. V.; Oliveira Filho, L. C. I. Adubação fosfatada para cultivares de mamoneira no Rio Grande do Sul. Ciência Rural, v.40, p.1835-1839, 2010. https://doi. org/10.1590/S0103-84782010000800027

Peuke, A. D.; Jeschke, W. D.; Hartung, W. F. Flows of elements, ions and abscisic acid in Ricinus communis and site of nitrate reduction under potassium limitation. Journal of Experimental Botany, v.53, p.241-250, 2002. https://doi.org/10.1093/jexbot/53.367.241 
PROBIODIESEL - Programa Brasileiro de Desenvolvimento Tecnológico de Biodiesel. Available on: <http://www.ipef.br/ legislacao/bdlegislacao/arquivos/14167.rtf $>.2002$.

Ribeiro, S.; Chaves, L. H. G.; Guerra, H. O. C.; Gheyi, H. R.; Lacerda, R. D. de. Resposta da mamoneira cultivar BRS-188 Paraguaçu à aplicação de nitrogênio, fósforo e potássio. Revista Ciência Agronômica, v.40, p.465-473, 2009.

Severino, L. S.; Ferreira, G. B.; Moraes, C. R. de A.; Gondim, T. M. de S.; Freire, W. S. de A.; Castro, D. A. de; Cardoso, G. D.; Beltrão, N. E. de M. Crescimento e produtividade da mamoneira adubada com macronutrientes e micronutrientes. Pesquisa Agropecuária Brasileira, v.41, p.563-568, 2006. http://dx.doi.org/10.1590/ S0100204X2006000400003

Severino, L. S.; Vale, L. S. do; Cardoso, G. D.; Beltrão, N. E. M.; Santos, J. W. dos. Método para determinação da área foliar da mamoneira. Campina Grande: Embrapa Algodão, 2005. 20p. Boletim de Pesquisa e Desenvolvimento, 55
Silva, D. F. da; Trindade, R. C. P.; Oliveira, M. W. de; Ferro, J. H. de A.; Calheiros, A. S. Crescimento vegetativo e produtividade de mamoneira em função da variedade e da adubação fosfatada. Revista Caatinga, v.25, p.160-167, 2012.

Silva, S. D.; Rodrigues, O. D.; Leandro, W. M. Análise de componentes da produção da mamoneira em função da adubação NPK no cerrado goiano. Enciclopédia Biosfera, v.9, p.115-127, 2013.

Silveira, T. C.; Pegoraro, R. F.; Portugal, S. F.; Resende, A. A. Produção da mamoneira submetida a combinações com fontes de fósforo e calagem. Revista Brasileira de Engenharia Agrícola e Ambiental, v.19, p.52-57, 2015. https://doi.org/10.1590/1807-1929/agriambi. v19n1p52-57

Souza, K. S.; Oliveira, F. A. de; Guedes Filho, D. H.; Brito Neto, J. F. de. Avaliação dos componentes de produção da mamoneira em função de doses de calcário e fósforo. Revista Caatinga, v.22, p.116-122, 2009. 